\title{
Childhood Infectious Disorder
}

National Cancer Institute

\section{Source}

National Cancer Institute. Childhood Infectious Disorder. NCI Thesaurus. Code C128321.

An infectious disorder that occurs in childhood. 